\title{
CORRESPONDENCE
}

\section{PALAEOZOIC OROGENY IN NORTH-WEST MALAYA}

SIR,-Dr. Koopmans has made a notable contribution to Malayan geology in demonstrating (Geol. Mag., 102, no. 6, 501-520) the occurrence of a post-Cambrian orogeny prior to the main Mesozoic revolution " Pacific orogeny"). This has long been suspected, but not previously established.

The dating assigned to this "Langkawi folding phase", however, is unfortunately based on only part of the available evidence. A more detailed appraisal of the regional geology indicates that the suggested SilurianDevonian date for these movements cannot be sustained. This question is of primary importance to the elucidation of south-east Asian geology and seems to merit discussion.

Koopmans' field of investigation lies in the extreme north-west of Malaya and on the eastern edge of the Palaeozoic shelf. The restriction of intense deformation to the Lower Palaeozoic rocks in the south-east and east of this area may thus be due to the stable (platform) tectonic situation of the strata farther west, rather than to their more recent (Upper Palaeozoic) date. In this context it is significant that strong metamorphism is not reported from the argillites of the lower part of the Upper Cambrian Machinchang Formation in the west of Pulau Langkawi.

Dating of the deformation is best established by reference to the basin where unconformities, on which Koopmans places considerable reliance, are characteristically fewer and where, due to the tectonic milieu and consequent nature of the sedimentary rocks, orogenic movements are more clearly expressed.

Some 450 square miles of Ordovician to Middle Devonian euxinic basin facies (the Mahang Formation) have been mapped by the present writer and his colleagues on the north-west Malayan mainland. Many of the structural features described from the Setul Formation, particularly those on Pulau Langgon and Pulau Tembus Dendang, are duplicated here. Fossil localities are numerous, but no remains of Middle or Upper Silurian age have been proven. This palaeontological hiatus would appear, however, to result not from major orogenic activity, but from the isolation of the euxinic basin from the open sea by the emergence of the confining geanticlinal barrier to the east. Emplacement of granite, envisaged in the Langkawi folding phase, is particularly unlikely at this stage of geosynclinal evolution. This interval is probably of greater duration in the Langkawi Islands, where the Upper Llandovery to Lower Devonian (inclusive) sequence appears to be missing. Koopmans' reference to Upper Silurian fossils here would seem to be erroneous.

The Mahang Formation of the basin is succeeded with little or no break by the Middle Devonian to Lower Carboniferous Kampong Sena Formation. In part the latter is of flysch facies, apparently indicative of contemporaneous, or imminent, orogeny. This conclusion is supported by the total absence (Procter, personal communication) of confirmed Middle and Upper Carboniferous strata from Malaya.

The Devonian of the north-west Malayan basin does not conspicuously exhibit the alleged "incompleteness" and, although apparently unbeknown to Koopmans, Devonian strata are also present in the Langkawis-evidenced by the occurrence on Pulau Langgon of the trilobite Cyrtosymbole (Cyrtodechenella) of Middle Devonian age (Kobayashi, personal communication ; Burton, 1965, p. 788) and by Middle Devonian Styliolinids and Nowakiids (Bouček, personal communication). Moreover, Devonian rocks probably occur in Thailand too. At Na Suan, some 150 miles W.N.W. of Bangkok, tentaculites were found which Duncan (in Brown et al., 1953, p. 33) referred to "Styliolina clavula" and "Tentaculites elegans". The former is a synonym of Styliolina fissurella (Middle Devonian) and Barrande's "Tentaculites elegans" is now recognized as comprising several (Lower to Middle Devonian) species of Nowakia (Bouček, 1964, p. 59. 80). 
The Kampong Sena Formation of the mainland is clearly equivalent, in part at least, to the Singa Formation of Langkawi, and like the latter includes granite detritus and fragments of metamorphosed argillites.

The succeeding Permian Chuping Limestone of Malaya and Rat Buri Limestone of Thailand appear to represent the early, platform, facies of a new sedimentary cycle or sub-cycle.

It is therefore contended that the "Langkawi folding phase" is most probably of Middle to Upper Carboniferous date and constitutes the culmination of a clearly defined Upper Cambrian to Lower Carboniferous cyle of sedimentation.

\section{REFERENCES}

BouČEK, B. (1964). The Tentaculites of Bohemia: Their Morphology, Taxonomy, Phylogeny, and Biostratigraphy: Prague, Publishing House of Czech Academy of Sciences, $215 \mathrm{p}$.

Brown, G. F. et al. (1953). Geologic Reconnaissance of the Mineral Deposits of Thailand : Geological Survey Memoir 1 : Bangkok, Royal Dept. of Mines, $183 \mathrm{p}$.

Burton, C. K. (1965). Wrench Faulting in Malaya: J. Geol., 73, 781-98. Koopmans, B. N. (1965). Structural Evidence for the Presence of a Palaeozoic Orogeny in North-West Malaya: Geol. Mag., 102, 501-20.

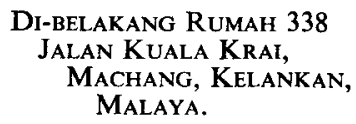

\section{NOTE ON ASSOCIATION OF PENTACRINUS WITH LIGNITE}

SIR,-It has been remarked from the days of the Rev. Prof. Buckland onwards that the splendid groups of Pentacrinus briareus for which Lyme Regis is famous, and which adorn most museum collections of Lias fossils, are usually so closely associated with masses of lignite (resembling a friable jet), that there can be no reasonable doubt that the crinoids grew attached to driftwood floating in the Liassic sea. Collectors, however, seem not to have recorded whether the lignite occurs above or below the crinoid remains, and as the clusters of Pentacrini are rarely observable in situ, opportunities for observation do not often present themselves.

In the course of the year 1957 I had the good fortune, on two occasions, to see specimens, in situ, and in both cases, the lignite lay above the crinoids. In the first instance, a long slice of the "Pentacrinite Bed" with associated strata above and below, to a thickness of some 8 or 9 feet, had slipped from the face of Stonebarrow Cliff without turning over in its descent to the beach, and in this mass was visible the edge of a thin group of crinoids, about 2 feet across, capped by a layer of lignite. Another and thinner seam of the characteristic white crinoidal limestone occurred in another part of the great slumped block, but at least 18 inches lower. No lignite was visible, but this specimen may have shown only the fringe of a group extending beyond the limits of any lignite to which it may have been attached. The difference in horizon of the two specimens is interesting, as indicating that the crinoids may range through an appreciable thickness of strata, and certainly are not confined to one bedding-plane.

In the second case, three small groups, in friable condition and considerably damaged by wave action, were visible in plan, several yards apart, near low-water mark, on the shore-platform below Stonebarrow Cliff, a short distance east of the spot where the Flatstones Nodules are faulted down to beach-level. In each instance a small crust of lignite still clung to the upper surface of the groups. This is the only place where the "Pentacrinite Bed " comes down to the shore ; but, unfortunately, the whole area is almost always 